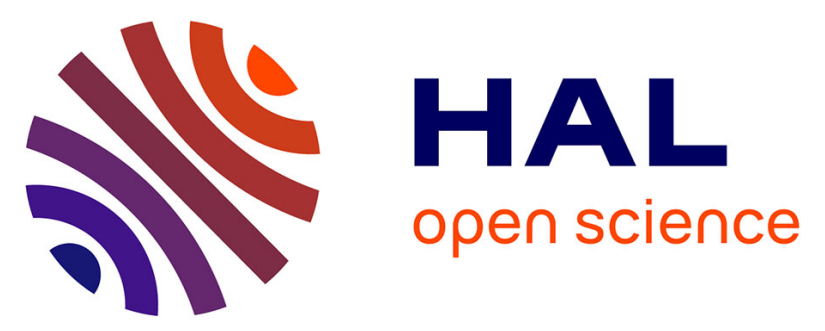

\title{
A new mixed pyrazole-diamine/Ni(II) complex, Crystal structure, physicochemical, thermal and antibacterial investigation
}

Abderrahim Titi, Saud M Almutairi, Rachid Touzani, Mouslim Messali, Monique Tillard, Belkheir Hammouti, Mohamed El Kodadi, Driss Eddike, Abdelkader Zarrouk, Ismail Warad

\section{To cite this version:}

Abderrahim Titi, Saud M Almutairi, Rachid Touzani, Mouslim Messali, Monique Tillard, et al.. A new mixed pyrazole-diamine/Ni(II) complex, Crystal structure, physicochemical, thermal and antibacterial investigation. Journal of Molecular Structure, 2021, 1236, pp.130304. 10.1016/j.molstruc.2021.130304 . hal-03180506

\section{HAL Id: hal-03180506 https://hal.science/hal-03180506}

Submitted on 25 Mar 2021

HAL is a multi-disciplinary open access archive for the deposit and dissemination of scientific research documents, whether they are published or not. The documents may come from teaching and research institutions in France or abroad, or from public or private research centers.
L'archive ouverte pluridisciplinaire HAL, est destinée au dépôt et à la diffusion de documents scientifiques de niveau recherche, publiés ou non, émanant des établissements d'enseignement et de recherche français ou étrangers, des laboratoires publics ou privés. 


\title{
A new mixed pyrazole-diamine/Ni(II) complex, Crystal structure, physicochemical, thermal and antibacterial investigation
}

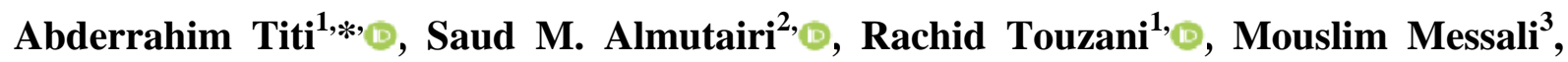 \\ Monique Tillard $^{4}{ }^{4}$, Belkheir Hammouti ${ }^{1}{ }_{\odot}$, Mohamed El Kodadi ${ }^{1}$, Driss Eddike ${ }^{5}$, \\ Abdelkader Zarrouk ${ }^{6}$, Ismail Warad ${ }^{7} *$
}

${ }^{1}$ Laboratory of Applied and Environmental Chemistry, Mohammed First University, Oujda, Morocco (LCAE).

${ }^{2}$ King Abdulaziz City for Science and Technology, Riyadh 11442, P.O. Box 6086, Saudi Arabia

${ }^{3}$ Department of Chemistry, Faculty of Science, Taibah University, Al-Madinah Al-Munawarah, Saudi Arabia ${ }^{4}$ ICGM, Univ. Montpellier, CNRS, ENSCM, Montpellier, France

${ }^{5}$ Laboratory of Inorganic Solid State Chemistry, Mohammed First University, Oujda, Morocco. ${ }^{6}$ Laboratory of Materials, Nanotechnology and Environment, Faculty of Sciences, Mohammed V University, Av. Ibn Battouta, P.O. Box 1014, Agdal-Rabat, Morocco

${ }^{7}$ Department of Chemistry and Earth Sciences, PO Box 2713, Qatar University, Doha, Qatar

Corresponding authors: E-mail address: titi_abderrahim1718@upm.ac.ma, ismail.warad@qu.edu.qa

\begin{abstract}
:
The new mixed complex $\left\{\left[2 \mathrm{Ni}(\mathrm{L} 1)_{2} \cdot 2 \mathrm{Ni}(\mathrm{L} 1)(\mathrm{L} 2)\right] .2\left(\mathrm{NO}_{3}\right)_{4} \cdot 2 \mathrm{H}_{2} \mathrm{O}\right\}$ was obtained from a mixture, under aerobic conditions, of a solution of $\mathrm{Ni}\left(\mathrm{NO}_{3}\right)_{2}, 6 \mathrm{H}_{2} \mathrm{O}$ and the two diamine pyrazolic ligands L1, N1-((3,5-dimethyl-1H-pyrazol-1-yl)methyl)propane-1,2-diamine, and L2, N2-((3,5-dimethyl-1H-pyrazol-1-yl)-methyl)propane-1,2-diamine. Obtained in very good yield, this complex was identified and characterized by FT-IR, EDX, ultraviolet-visible spectroscopies and single-crystal X-ray diffraction (XRD). The structural peculiarity is that two isomeric forms of molecules $\mathrm{C}_{18} \mathrm{H}_{36} \mathrm{~N}_{8} \mathrm{Ni}$ have co-crystallized with $\mathrm{H}_{2} \mathrm{O}$ and $\mathrm{NO}_{3}$ molecular units. The triclinic structure of P1 symmetry is stabilized by the numerous hydrogen bonds that occur in the crystal lattice. The thermal behavior of this $\mathrm{Ni}(\mathrm{II})$ complex was studied in an open atmosphere via TG/DTG. The L1, L2 ligands and the Ni(II) complex were evaluated for their antibacterial activity against a series of Gram-negative and Grampositive bacteria.
\end{abstract}

Keywords: Nickel(II); pyrazole; crystal structure; biological evaluations. 


\section{Introduction}

Pyrazole molecules, capable of binding as polychelate ligands, constitute a class of interest among organic compounds. They have been used as starting materials in the synthesis of many compounds with important biological activities [1-3]. They have an essential role in therapeutic chemistry as shown by the examples of celecoxib as an anti-inflammatory agent and COX-2 inhibitor [4,5], fomepizole as an alcohol dehydrogenase inhibitor [6-8], sildenafil as a phosphodiesterase inhibitor $[9,10]$ and rimonabant in the treatment of obesity $[11,12]$. The complexation chemistry of pyrazole-based ligands has attracted significant attention due to their high potential for use with all transition metal ions [13-14]. Hybrid materials have acquired significant importance not only because of their structural diversity but also because of their multiple properties which can be exploited in a wide range of applications such as catalysis [15-19], optics [20], magnetic cooling [21], separation [22], dye adsorption [23], photo-luminescence [24], or for their anti-cancer [25], antimicrobial [26], fungicidal [27], anti-inflammatory [28], antiviral [29] and anti-oxidant behavior [30,31].

Recently, we have been working on the preparation of several types of pyrazole derivatives. The structures, spectral, physicochemical, catalytic and biological properties of the specific polychelate pyrazole coordinated to nickel, copper and cobalt transition metal ions have been clarified [15-19].

In the present project, we report on the preparation, characterization, spectral, structure, thermal, antimicrobial and XRD studies of the novel $\left\{\left[2 \mathrm{Ni}(\mathrm{L} 1)_{2} \cdot 2 \mathrm{Ni}(\mathrm{L} 1)(\mathrm{L} 2)\right] .2\left(\mathrm{NO}_{3}\right)_{4} \cdot 2 \mathrm{H}_{2} \mathrm{O}\right\}$ mixed complex.

\section{Materials and Methods}

\subsection{Materials and physical measurements}

$\mathrm{Ni}\left(\mathrm{NO}_{3}\right)_{2}, 6 \mathrm{H}_{2} \mathrm{O}$ salt and propane-1,2-diamine were purchased from Sigma-Aldrich, the pyrazole ligands were synthesized by reacting (3,5-dimethyl-1H-pyrazol-1-yl) methanol with paraformaldehyde [17]. The IR spectra were recorded at room temperature (RT) in the range 4000-400 $\mathrm{cm}^{-1}$ using a Perkin Elmer FT- IR spectrometer and the UV-Vis spectra using a UV-1280 Shimadzu spectrometer.

\subsection{Ligands and Complex Synthesis}


The N1-((3,5-dimethyl-1H-pyrazol-1-yl)methyl)propane-1,2-diamine $\left(\mathbf{L}_{\mathbf{1}}\right)$ and N2-((3,5 dimethyl-1H-pyrazol-1-yl)methyl)propane-1,2-diamine $\left(\mathbf{L}_{\mathbf{2}}\right)$ ligands were synthesized by reacting (3,5-dimethyl-1H-pyrazol-1-yl)methanol with propane-1,2-diamine in acetonitrile solution. As the selection between the different possible ligands cannot be easily operated, the reaction stock solution was then used as is in the synthesis of the $\mathrm{Ni}(\mathrm{II})$ complex (Scheme 1). $\mathrm{Ni}\left(\mathrm{NO}_{3}\right)_{2}, 6 \mathrm{H}_{2} \mathrm{O}(50 \mathrm{mg}, 0.21 \mathrm{mmol})$ was solved in $15 \mathrm{~mL}$ of $\mathrm{MeOH}$. The mixture was then added to a solution containing $100 \mathrm{mg}$ each of $\left(\mathbf{L}_{\mathbf{1}}\right)$ and $\left(\mathbf{L}_{\mathbf{2}}\right)$ ligands dissolved in $20 \mathrm{~mL}$ acetone. The mixture was sealed and stirred for two hours until the solution turned bluebrown. The solution was then filtered to remove solid impurities. Crystals were obtained by recrystallization from the evaporation of a 1:1 mixture of methanol and acetone solvents.

\subsection{Biological studies}

The biological studies were carried out using methods recently reported and available in the literature [30].

\subsection{X-ray crystal structure determination}

Using a stereomicroscope equipped with a polarizing filter, the search for a suitable single crystal for X-ray experiments allowed us to select a nice diamond-shaped and pink-purplecolored platelet. The diffracted intensities were collected at room temperature on a Bruker D8 Venture 4-circle diffractometer equipped with an Incoatec I $\mu$ S 3.0 Mo micro source $(110 \mu \mathrm{m}$ beam, $\mathrm{K} \alpha$ radiation $\lambda=0.71073 \AA$ ) and a Photon II CPAD detector. The Apex software suite [33] was used for data processing and Lorentz-polarization corrections, and a multi-scan SADABS absorption correction was applied. The structure was solved and refined by fullmatrix least-squares on $\mathrm{F}^{2}$ using the SHELX programs [34, 35]. Positional and anisotropic displacement parameters were refined for all non- $\mathrm{H}$ atoms. The $\mathrm{H}$ atoms were detected in the final Fourier difference map and, except for the freely refined amine and ammonium $\mathrm{H}$ atoms, were refined using AFIX instructions and displacement parameters equal to 1.2 times (1.5 for $\left.-\mathrm{CH}_{3}\right)$ the $\mathrm{U}_{\mathrm{eq}}$ of the parent atom. The crystal data and main refinement parameters are given in Table 1. 
Table 1. Crystal data and refinement parameters

\begin{tabular}{lc}
\hline Formula & $4 \mathrm{C}_{18} \mathrm{H}_{36} \mathrm{~N}_{8} \mathrm{Ni}, 8 \mathrm{NO}_{3}, 2 \mathrm{H}_{2} \mathrm{O}$ \\
\hline CCDC number & 2048350 \\
Temperature & $293(2) \mathrm{K}$ \\
Crystal system & Triclinic, $\mathrm{P} 1$ \\
Lattice dimensions & $\mathrm{a}=11.301(3), \mathrm{b}=15.942(4), \mathrm{c}=16.511(5) \AA$ \\
& $\alpha=107.94(1), \beta=90.86(1), \gamma=103.535(9){ }^{\circ}$ \\
Volume & $2739.0(13) \AA^{3}$ \\
Density (calculated) & $1.349 \mathrm{Mg} / \mathrm{m}^{3}$ \\
$\mathrm{~F}(000)$ & 1180 \\
Crystal size & $0.28 \times 0.20 \times 0.07 \mathrm{~mm}^{3}$ \\
Theta range & 2.53 to $27.38^{\circ}$. \\
Collected / independent reflections & $98743 / 24628\left[\mathrm{R}_{\text {int }}=0.0421\right]$ \\
Completeness to 25.24 & $99.9 \%$ \\
Data / restraints / parameters & $24628 / 9 / 1316$ \\
Goodness-of-fit on $\mathrm{F}^{2}$ & 1.007 \\
Final R indices $[\mathrm{I}>2 \sigma(\mathrm{I})]$ & $\mathrm{R} 1=0.0431, \mathrm{wR} 2=0.1067$ \\
R indices (all data) & $\mathrm{R} 1=0.0664, \mathrm{wR} 2=0.1205$ \\
Largest diff. peak and hole & 0.489 and $-0.307 \mathrm{e} . \AA^{-3}$ \\
\hline
\end{tabular}

\section{Results and discussion}

\subsection{Synthesis EDX, CHN-EA, molar conductivity and magnetic analysis}

According to the synthetic routes depicted in Scheme 1, the N1-((3,5-dimethyl-1Hpyrazol-1-yl)methyl)propane-1,2-diamine $\quad\left(\mathbf{L}_{\mathbf{1}}\right), \quad \mathrm{N} 2-((3,5 \quad$ dimethyl-1H-pyrazol-1yl)methyl)propane-1,2-diamine $\left(\mathbf{L}_{\mathbf{2}}\right)$ ligands were prepared by condensation of [1:1] $(3,5-$ dimethyl-1H-pyrazol-1-yl)methanol with propane-1,2-diamine in acetonitrile solution at room temperature. The GC-MS showed that the final mixture was composed with both the L1 and L2 ligands in a 3:1 ratio. The $\left\{\left[2 \mathrm{Ni}(\mathrm{L} 1)_{2} .2 \mathrm{Ni}(\mathrm{L} 1)(\mathrm{L} 2)\right] \cdot 2\left(\mathrm{NO}_{3}\right)_{4} \cdot 2 \mathrm{H}_{2} \mathrm{O}\right\}$ mixed complex was synthesized by reacting $\mathrm{Ni}\left(\mathrm{NO}_{3}\right)_{2}, 6 \mathrm{H}_{2} \mathrm{O}$ with this ligands $\left(\mathrm{L}_{1}\right.$ and $\left.\mathrm{L}_{2}\right)$ mixture in a solvent consisting of equal proportions of methanol and acetone. The pink-colored crystals were obtained in excellent yield by recrystallization under aerobic conditions. The desired complex is highly soluble in polar solvents. The CHN- and EDX analysis of the $\left\{\left[2 \mathrm{Ni}(\mathrm{L} 1)_{2} \cdot 2 \mathrm{Ni}(\mathrm{L} 1)(\mathrm{L} 2)\right] .2\left(\mathrm{NO}_{3}\right)_{4} \cdot 2 \mathrm{H}_{2} \mathrm{O}\right\}$ prepared complex confirmed the presence of $\mathrm{C}, \mathrm{N}$, $\mathrm{O}$ and $\mathrm{Ni}$ atoms (Fig. 1). 


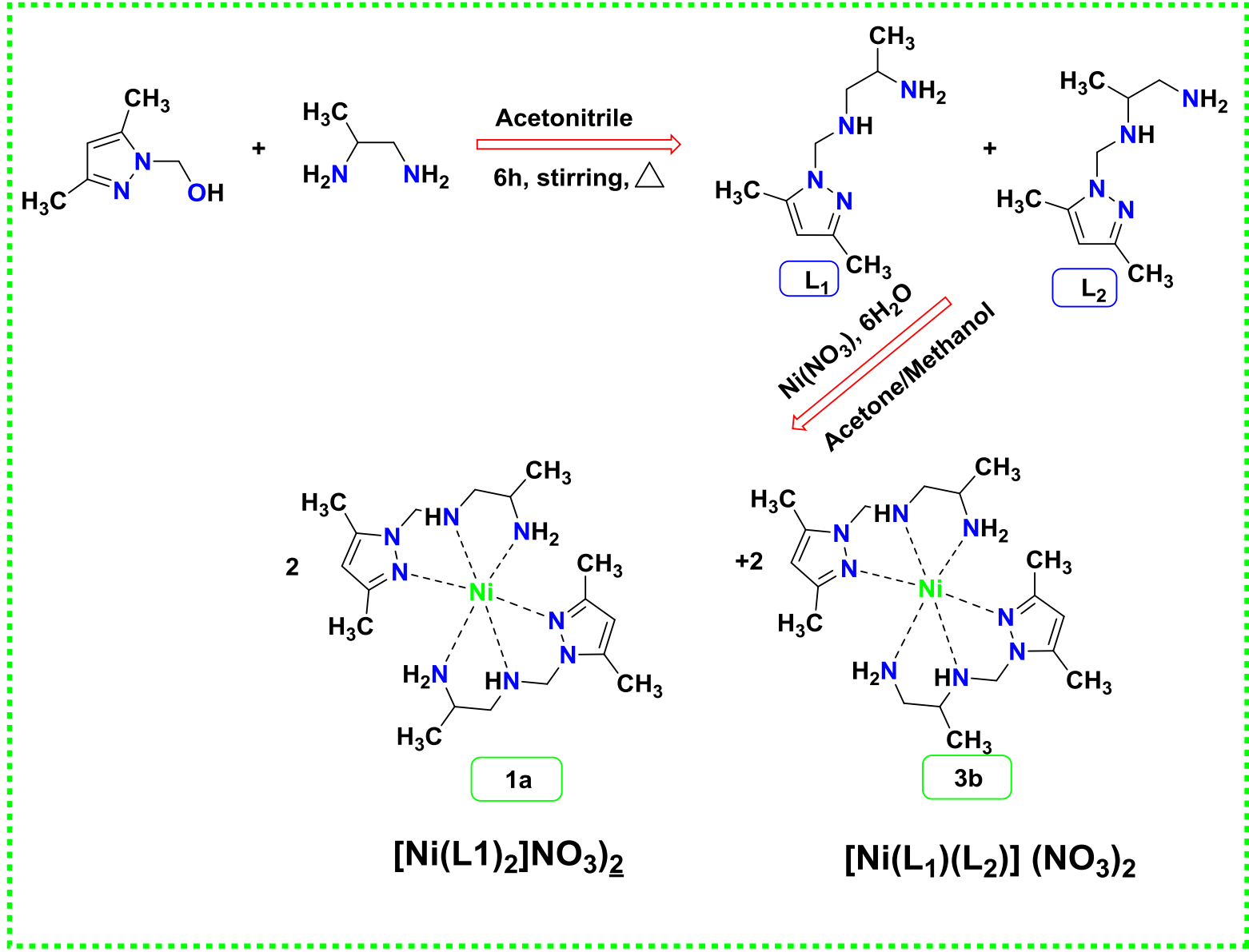

Scheme 1. Synthetic route for the ligands (L1 and L2) and the complex.

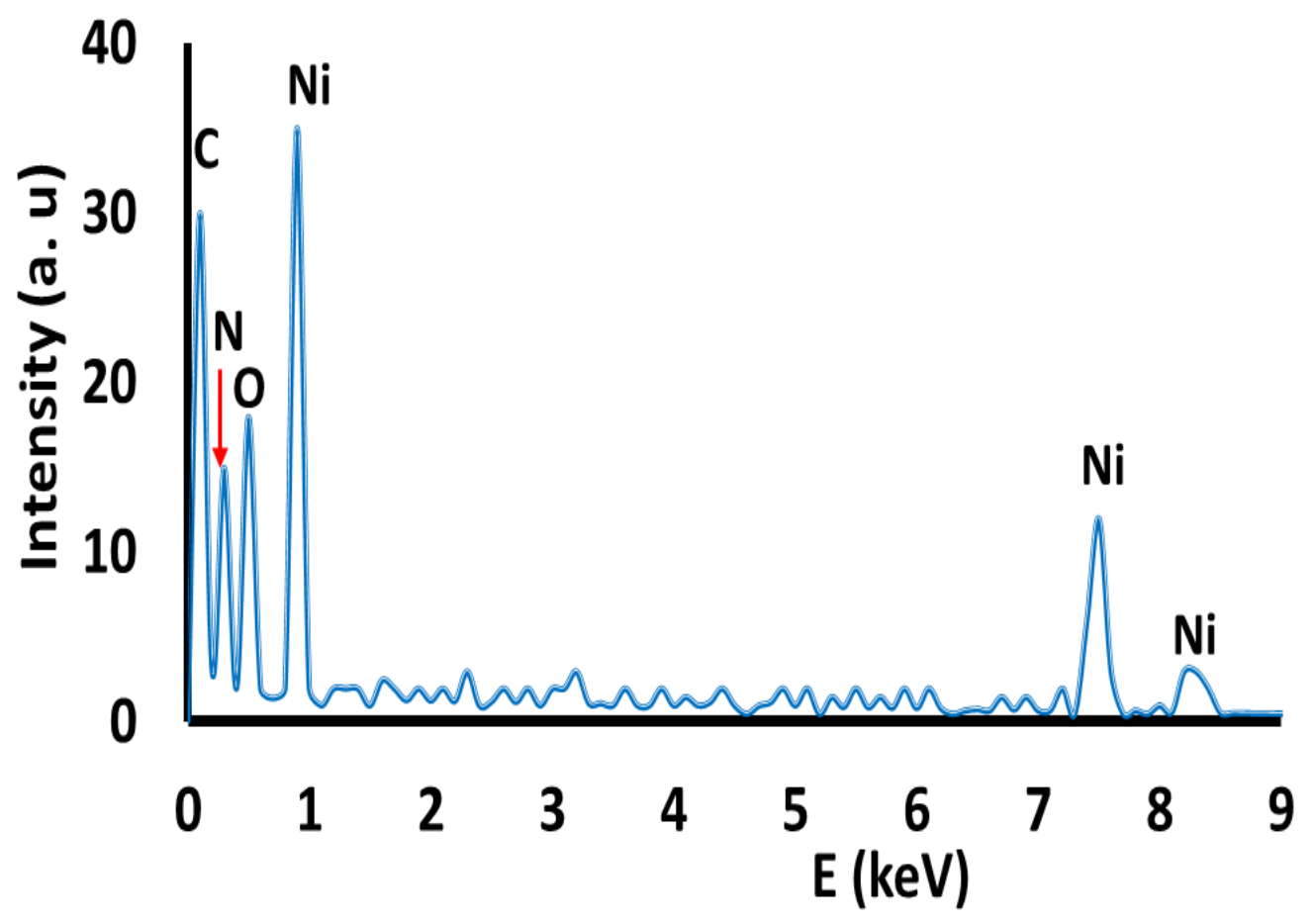


Fig. 1. EDX spectrum of the $\left\{\left[2 \mathrm{Ni}(\mathrm{L} 1)_{2} \cdot 2 \mathrm{Ni}(\mathrm{L} 1)(\mathrm{L} 2)\right] \cdot 2\left(\mathrm{NO}_{3}\right)_{4} \cdot 2 \mathrm{H}_{2} \mathrm{O}\right\}$ complex.

The magnetic susceptibility and the molar conductivity were measured at room temperature for a solution $1 \times 10^{-3} \mathrm{M}$ of the complex dissolved in water, they were found to be $3.35 \mathrm{BM}$ and $56.5 \mathrm{~S} . \mathrm{cm}^{2} . \mathrm{mol}^{-1}$, respectively.

\subsection{Crystal structure description}

The data set of reflections was indexed in a triclinic lattice of dimensions $\mathrm{a}=11.301(3)$, $\mathrm{b}=15.942(4), \mathrm{c}=16.511(5) \AA, \alpha=107.940(13), \beta=90.858(10), \gamma=103.535(9)^{\circ}$ and the structure was solved in the non-centrosymmetric P1 space group. The unit cell content corresponds to a global formula $\mathrm{C}_{72} \mathrm{H}_{148} \mathrm{~N}_{40} \mathrm{Ni}_{4} \mathrm{O}_{26}$ and a density of $1.35 \mathrm{Mg} / \mathrm{m}^{3}$.

According to the reaction given in Scheme 1, both ligands $\mathrm{L}_{1}$ and $\mathrm{L}_{2}$ may form in solution and can coordinate the $\mathrm{Ni}$ (II) metal centers to give the complex of formula $\mathrm{Ni}\left(\mathrm{C}_{18} \mathrm{H}_{36} \mathrm{~N}_{8}\right)$ as the main component, as the isomer 1a (two ligands L1) or the isomer 3 b (one L1 and one L2). During the crystallization process, four molecules of the Ni complex have co-crystallized with both nitric acid and water molecules providing a solid compound composed of one diprotonated unit of type $1 \mathrm{a}$, three di-protonated units of type $3 \mathrm{~b}$, eight anionic $\mathrm{NO}_{3}{ }^{-}$units and two water molecules per lattice (Fig. 2). Similar situations have already been reported. As an example, we can cite the case of a cadmium mononuclear complex including pyrazole whose crystal structure contains two enantiomers [41], or that of a mononuclear complex of iron crystallized with $\mathrm{NO}_{3}$ and $\mathrm{H}_{2} \mathrm{O}$ molecular units [42].

Therefore, the solid compound should be formulated using one of the following alternatives, either with the global atomic content $\mathrm{C}_{72} \mathrm{H}_{148} \mathrm{~N}_{40} \mathrm{Ni}_{4} \mathrm{O}_{26}$ or with the formal content $\left[\left(\mathrm{Ni}\left(\mathrm{C}_{9} \mathrm{H}_{17} \mathrm{~N}_{4}\right)_{2}\right)_{4}, \quad\left(\mathrm{HNO}_{3}\right)_{8}, \mathrm{H}_{2} \mathrm{O}\right]$ or even with the ionic-molecular content $\left[\left(\mathrm{Ni}\left(\mathrm{C}_{18} \mathrm{H}_{36} \mathrm{~N}_{8}\right)^{2+}\right)_{4},\left(\mathrm{NO}_{3}{ }^{-}\right)_{8},\left(\mathrm{H}_{2} \mathrm{O}\right)_{2}\right]$. 

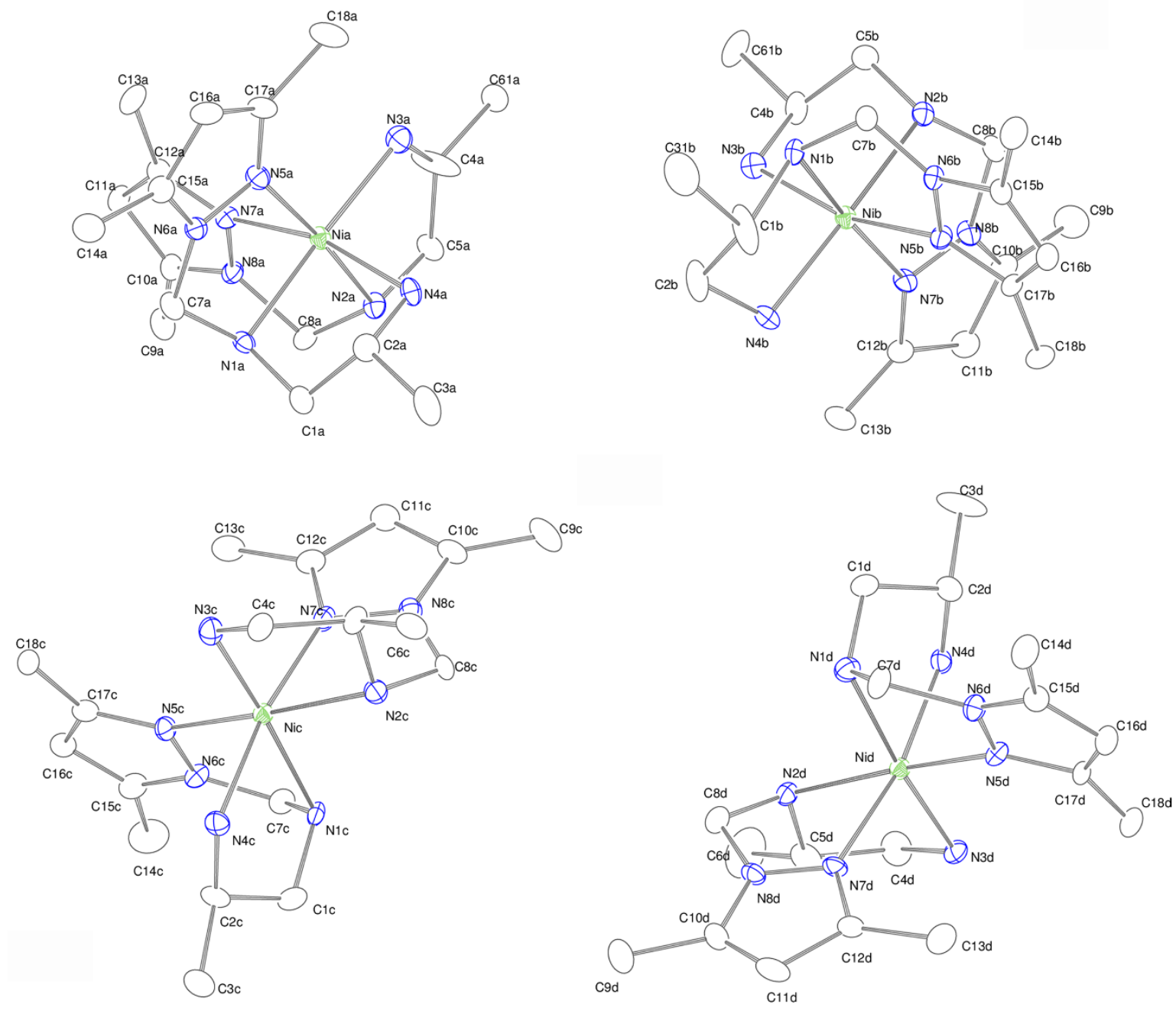

Fig. 2. Molecular units $\mathrm{C}_{18} \mathrm{H}_{36} \mathrm{~N}_{8} \mathrm{Ni}^{2+}$, of the type $\mathbf{1 a}$ at $\mathrm{Ni}_{\mathrm{a}}$ and the type $3 \mathbf{b}$ at $\mathrm{Ni}_{\mathrm{b}}, \mathrm{Ni}_{\mathrm{c}}$ and $\mathrm{Ni}_{\mathrm{d}}$ (in the same orientation). Atom labels are indicated and $\mathrm{H}$ atoms are omitted for clarity.

In each of the independent complex molecules, the $\mathrm{Ni}$ (II) center is coordinated by six nitrogen atoms at distances ranging from 2.051 to $2.186 \AA$ (see details in table 2), so that $\mathrm{Ni}$ atoms are placed in more or less distorted octahedral arrangements. It is interesting to remark that the average $\mathrm{Ni}-\mathrm{N}$ distance is the same for all the Ni centers, whether they are $1 \mathrm{a}$ or $3 \mathrm{~b}$ isomers. The magnitude of the angles $\mathrm{N}-\mathrm{Ni}-\mathrm{N}$ involving the $\mathrm{N}$ atoms in opposite positions, varying from 165.3 to $178^{\circ}$, gives an evaluation of these distortions from the ideal octahedral symmetry. The geometry deformation can be compared for example to the one of the iron complex cited above in which the corresponding angles range from 161 to $174^{\circ}$ [41]. 
Table 2. Distances $(\AA)$ around $\mathrm{Ni}(\mathrm{II})$ centers in the four independent molecules of the complex.

\begin{tabular}{llllllll}
\hline \multicolumn{2}{c}{ Nia } & & Nic & \multicolumn{2}{c}{ Nib } & \multicolumn{2}{c}{ Nid } \\
\hline N3a & 2.078 & N3c & 2.051 & N5b & 2.093 & N5d & 2.059 \\
N5a & 2.088 & N7c & 2.092 & N4b & 2.096 & N4d & 2.099 \\
N7a & 2.101 & N4c & 2.133 & N7b & 2.098 & N7d & 2.117 \\
N4a & 2.120 & N5c & 2.145 & N3b & 2.106 & N3d & 2.122 \\
N1a & 2.161 & N2c & 2.152 & N1b & 2.120 & N2d & 2.145 \\
N2a & 2.186 & N1c & 2.159 & N2b & 2.155 & N1d & 2.149 \\
\hline
\end{tabular}

Within the crystal solid-state structure, each molecular unit is involved in several H-bonds with the surrounding units as illustrated in the ORTEP drawing [36] given in Fig. 3. The molecules of the complex $\mathrm{C}_{18} \mathrm{H}_{36} \mathrm{~N}_{8} \mathrm{Ni}^{2+}$ are interconnected through $\mathrm{NO}_{3}$ and $\mathrm{H}_{2} \mathrm{O}$ units by numerous H-bonds, which are such as to strongly stabilize the molecular stacking, which brings an additional resemblance to the iron complex.

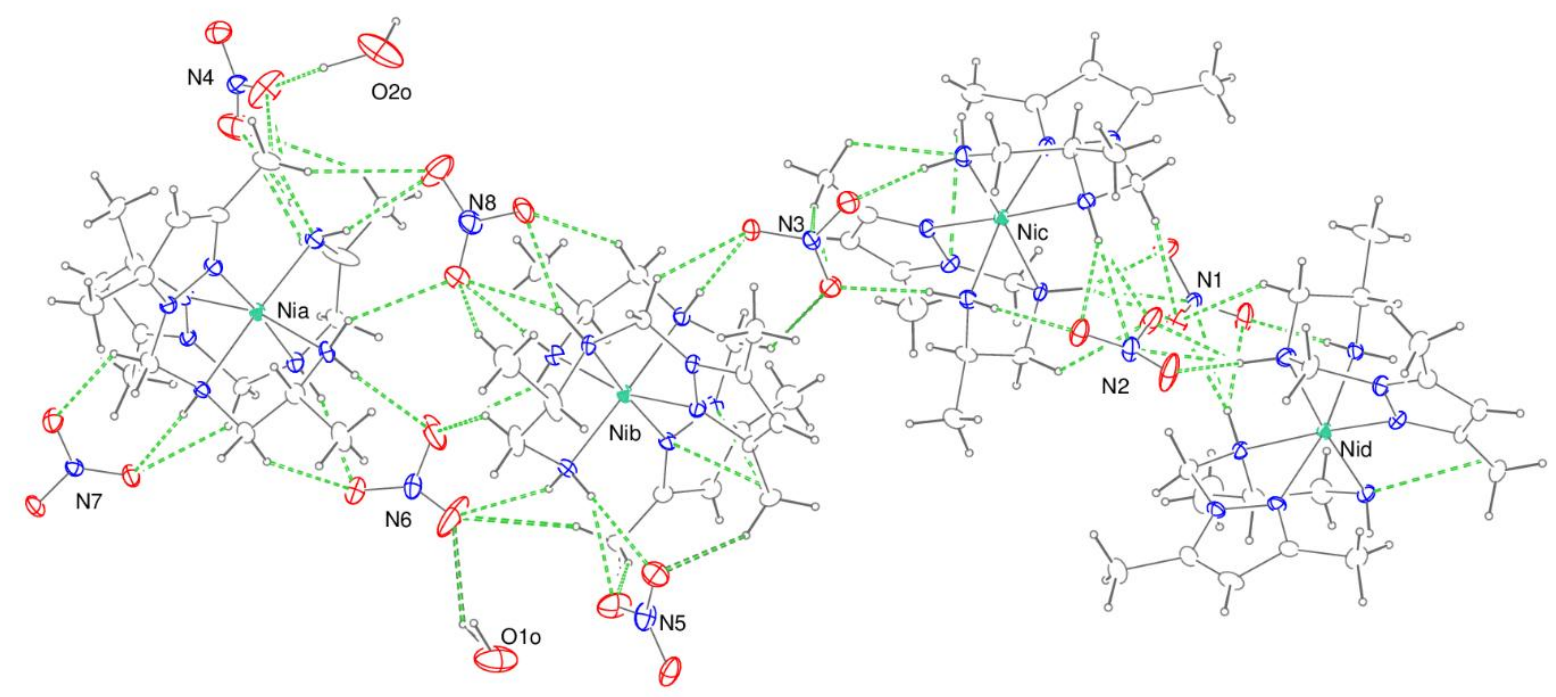

Fig. 3. Weak short contacts and H-bonding interactions (green dashed lines) within the asymmetric unit composed of $2 \times \mathrm{H}_{2} \mathrm{O}, 8 \times \mathrm{NO}_{3}{ }^{-}$and $4 \times \mathrm{C}_{18} \mathrm{H}_{36} \mathrm{~N}_{8} \mathrm{Ni}^{2+}$ molecular units, approximately viewed in the (011) plane (same orientation as Fig.2).

\subsection{FT-IR}


The FT-IR spectroscopy was used to investigate the coordination mode of the ligands $\mathrm{L}_{1}$ and $\mathrm{L}_{2}$ towards the $\mathrm{Ni}\left(\mathrm{NO}_{3}\right)_{2}, 6 \mathrm{H}_{2} \mathrm{O}$ salt. Such information is accessible from the comparison of IR spectra registered for the complex and for the free ligands that are given in Fig. 4. Several stretching vibrations, like Alkyl-H, N-H, O-H, C=N, C=C, N=O, N-O, N-Ni are located at their usual specific chemical wavenumbers [17]. The infrared spectra help to understand metal-ligand coordination behavior. The broad and sharp band observed at 3350 $\mathrm{cm}^{-1}$ in the IR spectrum of the complex results from the displacement of the band at $3243 \mathrm{~cm}^{-1}$ associated with $\mathrm{N}-\mathrm{H}$ bonds in ligands, which occurs with the bonding of the $\mathrm{N}$ atoms to the $\mathrm{Ni}$ (II) center.

Additionally, the signal at $488 \mathrm{~cm}^{-1}$ which occurs in the spectra of the complex is in agreement with the formation of a Ni-to-N bond [17, 37]. The signals associated with the $\mathrm{H}_{2} \mathrm{O}$ and $\mathrm{NO}_{3}$ molecules crystallized within the complex were observed at their usual frequencies, as a band at $3442 \mathrm{~cm}^{-1}$ of free $\mathrm{O}-\mathrm{H}$ and broadband at $\sim 1220 \mathrm{~cm}^{-1}$ for $\mathrm{NO}_{3}$.

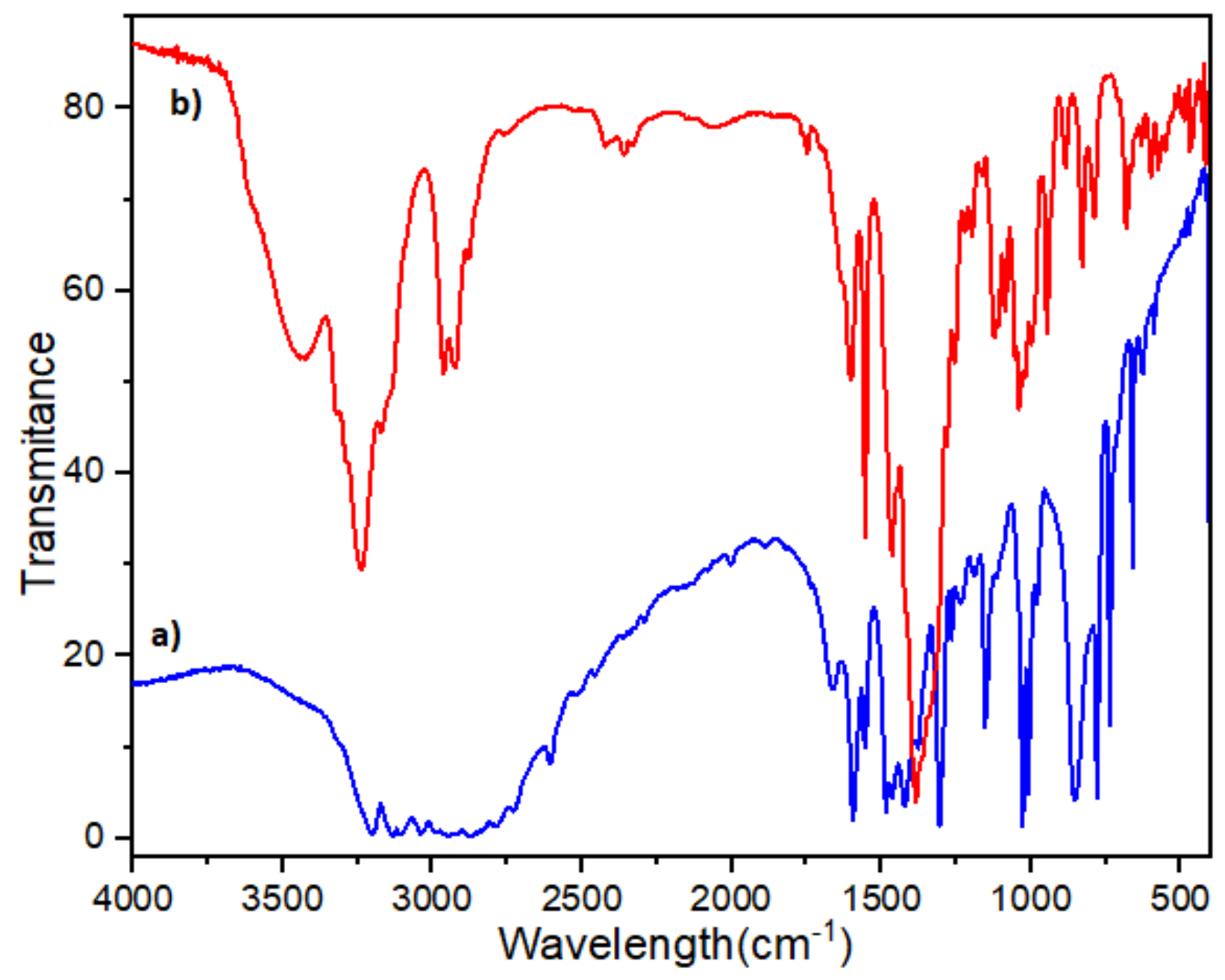

Fig. 4. Infrared spectra of (a) the free ligands, and (b) the complex. 


\subsection{UV-Visible}

The UV-visible electron transfer spectra recorded for the ligands and the corresponding complex $\left(1 \times 10^{-4} \mathrm{M}\right)$ in DMSO solution at room temperature are represented in Fig. 5.

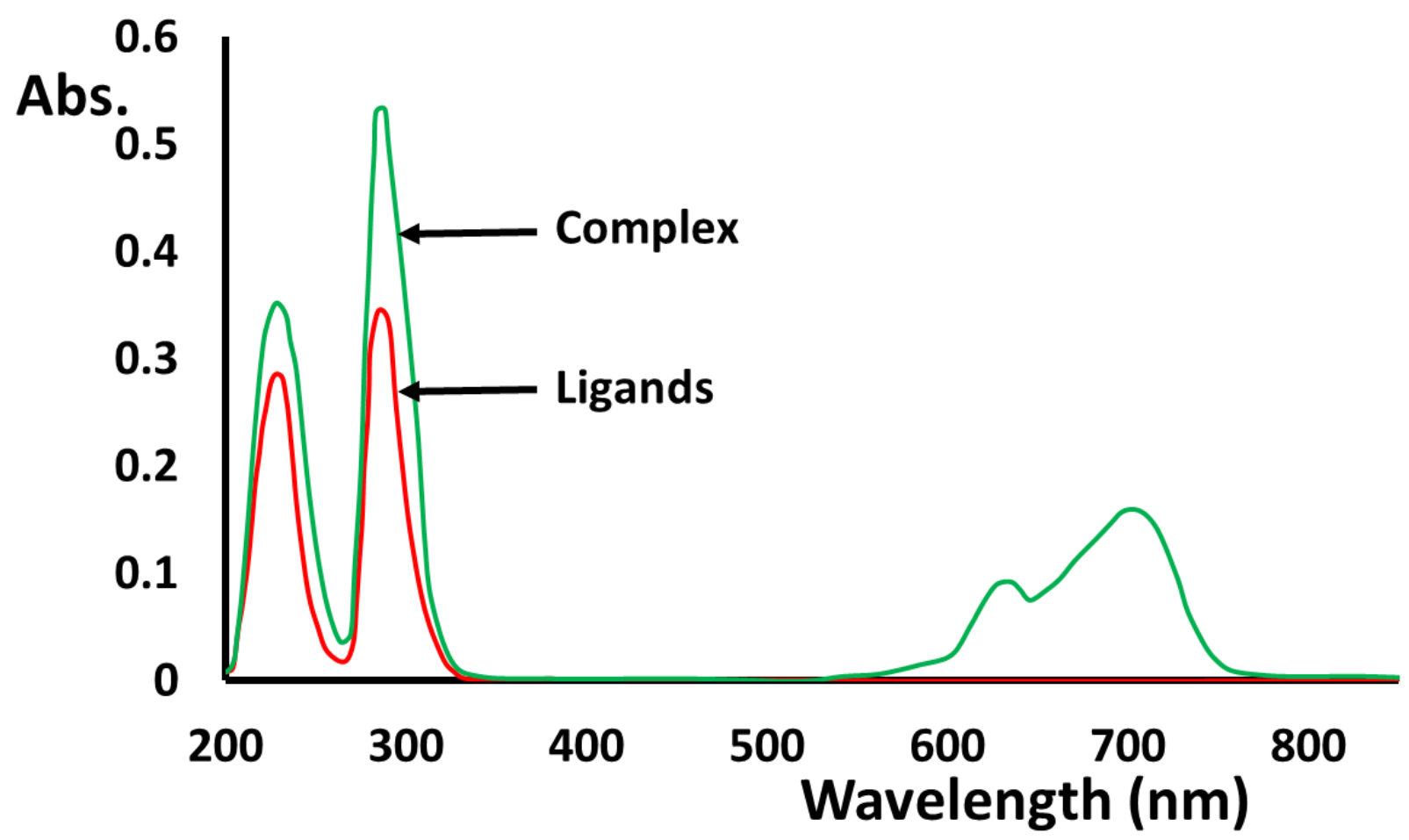

Fig. 5. UV- Visible spectra for ligands and complex in DMSO $\left(5 \times 10^{-5} \mathrm{M}\right)$.

As can be seen in Fig. 5, the spectrum recorded for a mixture of the free ligands shows the presence of only two bands in the UV domain at the wavelengths $\lambda_{\max }$ of $236 \mathrm{~nm}$ with $\varepsilon=$ $1.4 \times 10^{4} \mathrm{~L} / \mathrm{mol} \mathrm{cm}$ and $\lambda_{\max }$ of $298 \mathrm{~nm}$ with $\varepsilon=1.9 \times 10^{4} \mathrm{~L} / \mathrm{mol} \mathrm{cm}$. The electronic spectra registered for the Ni mixed complex also display two intense bands at these positions, the first is located at $236 \mathrm{~nm}\left(\varepsilon=1.1 \times 10^{4} \mathrm{~L} / \mathrm{mol} \mathrm{cm}\right)$ and the second at $298 \mathrm{~nm}\left(\varepsilon=1.6 \times 10^{4} \mathrm{~L} / \mathrm{mol}\right.$ $\mathrm{cm})$. These bands observed both for the free ligands and for the complex can be respectively associated with $\pi \rightarrow \pi^{*}$ and $n \rightarrow \pi^{*}$ electron transitions [34]. Two additional single absorption bands of medium intensity appear on the spectrum of the complex, they are centered at $\lambda_{\max }=$ $648 \mathrm{~nm}\left(\varepsilon=6.2 \times 10^{2} \mathrm{~L} / \mathrm{mol} \mathrm{cm}\right)$ and $698 \mathrm{~nm}\left(\varepsilon=8.6 \times 10^{2} \mathrm{~L} / \mathrm{mol} \mathrm{cm}\right)$ and have been assigned to a d-d electron transition, as is typically observed in such complexes [38]. 


\subsection{Thermal behavior}

The TG /DTG curves plotted in Fig. 6 were obtained for the Ni(II) mixed complex studied in this work. They are very similar to those previously reported for the pyrazolyl ligand-Nickel complex [38-40] indicating close thermal behavior for these two compounds. The direct and the difference thermogravimetric curves display four thermal events that can be attributed to the complex heated from the room temperature up to $700{ }^{\circ} \mathrm{C}$.

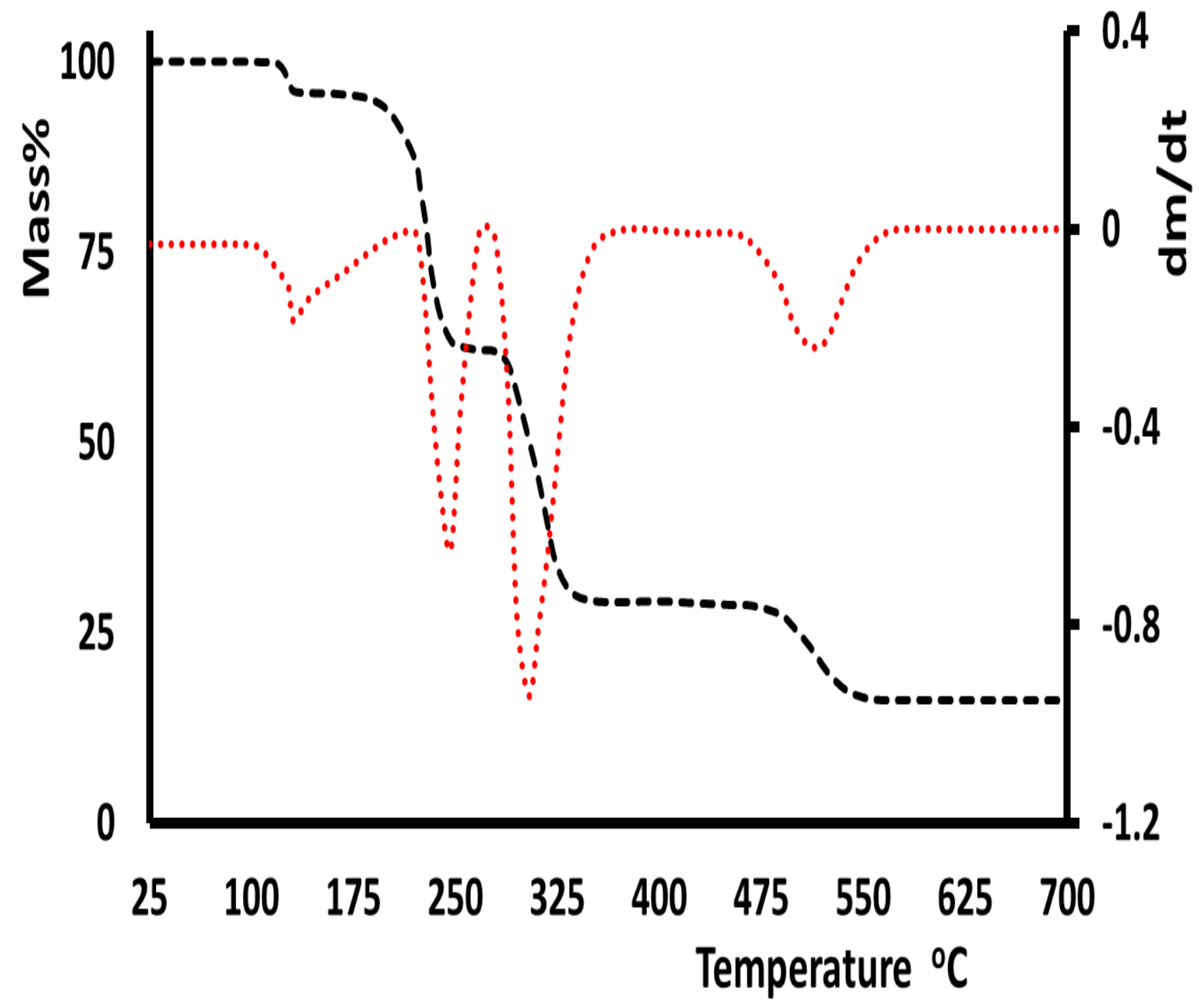

Fig. 6. TG/DTG curves for the $\mathrm{C}_{72} \mathrm{H}_{148} \mathrm{~N}_{40} \mathrm{Ni}_{4} \mathrm{O}_{26}$ complex with $5{ }^{\circ} \mathrm{C} \mathrm{min}^{-1}$ heating rate. 
The first step at $\sim 140-150{ }^{\circ} \mathrm{C}$ is associated with the dehydration of [Niligand $]\left(\mathrm{NO}_{3}\right)_{2} \cdot 2 \mathrm{H}_{2} \mathrm{O}$ to give the $[\mathrm{Ni}(\mathrm{L} 1)(\mathrm{L} 2)]\left(\mathrm{NO}_{3}\right)_{2}$ dehydrated complex via removal of two water molecules with $\mathrm{T}_{\mathrm{DTG}}=146{ }^{\circ} \mathrm{C}$ and $4.6 \%$ mass loss (4.8\% theoretical). The second and the third steps are assigned to pyrolysis of the diamine ligands at $180-240{ }^{\circ} \mathrm{C}$ with $\mathrm{T}_{\mathrm{DTG}}=240$ ${ }^{\circ} \mathrm{C}$ and $28.6 \%$ mass loss $(29 \%$ theoretical $)$, and $260-330{ }^{\circ} \mathrm{C}$ with $\mathrm{T}_{\mathrm{DTG}}=320{ }^{\circ} \mathrm{C}$ and $29.2 \%$ mass loss $\left(30 \%\right.$ theoretical) producing the $\mathrm{Ni}\left(\mathrm{NO}_{3}\right)_{2}$ molecular unit. The fourth step detected at $420-550{ }^{\circ} \mathrm{C}$ with $\mathrm{T}_{\mathrm{DTG}}=530{ }^{\circ} \mathrm{C}$ corresponds both to the removal of the $\mathrm{NO}_{3}$ ligand from $\mathrm{Ni}\left(\mathrm{NO}_{3}\right)_{2}$ and the reaction with $\mathrm{O}_{2}$ leading to the formation of $\mathrm{NiO}$ residue.

\subsection{Antimicrobial activities}

The search for highly active antimicrobial ligands and their complexes is of increasing interest to address the challenges associated with the emergence and the spread of new families of bacteria with high resistance to antibiotics [43-45].

Furthermore, the ligands and the complex were screened for their antimicrobial activities against four strains of microbes, which are recommended as a reference by the European Committee on Antimicrobial Susceptibility Testing (EUCAST), including two Gram-positive strains (S aureus, B. subtilis) and two Gram-negative strains (E. coli P. vulgaris).

For that, the agar diffusion method with Mueller-Hinton agar medium was used to determine the in vitro antimicrobial activities of the ligands and the complex. 


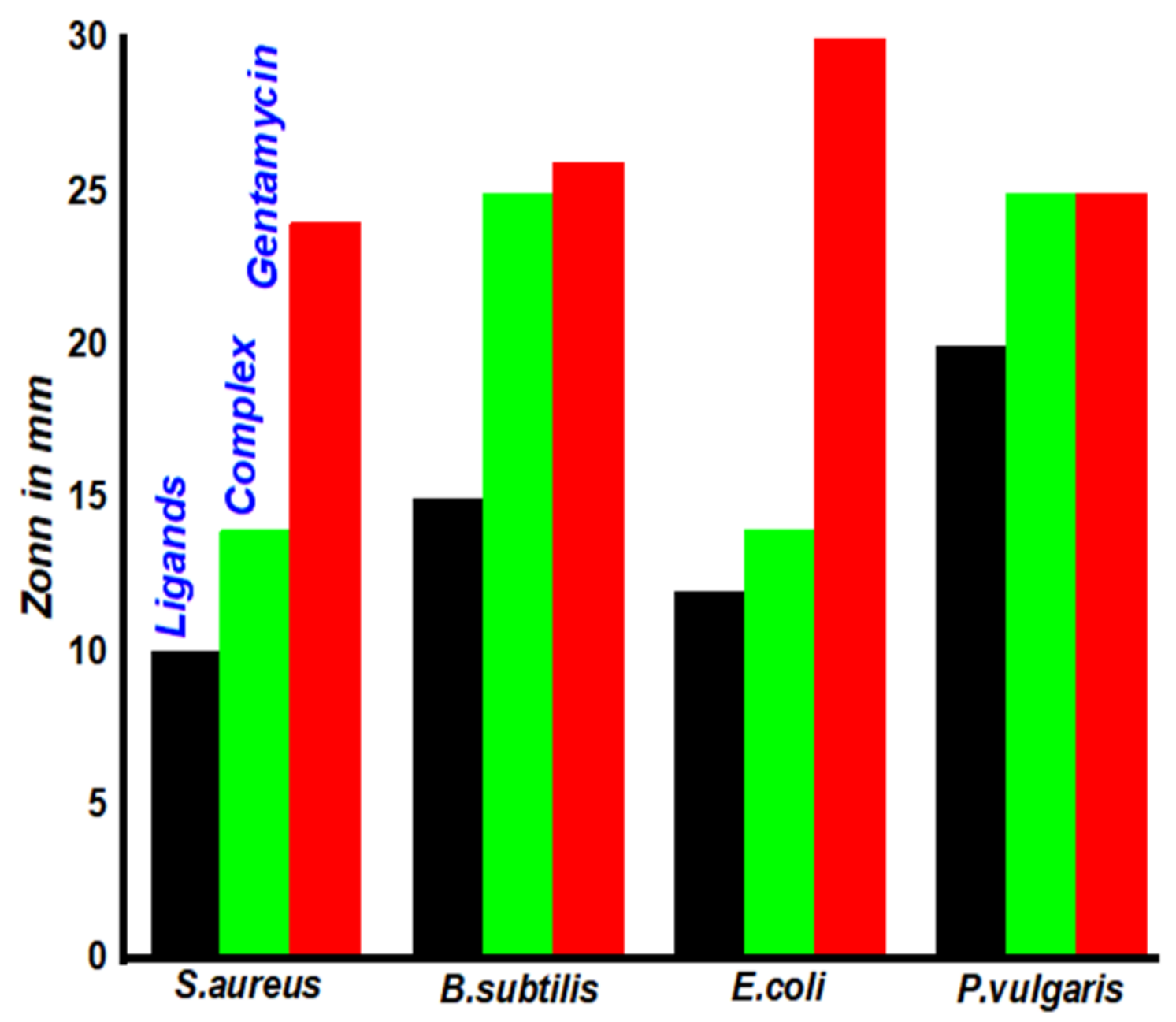

Fig 7. Antimicrobial activity for the ligands and the complex.

The main results obtained in these preliminary experiments are summarized in Fig. 7. They show that the ligands and the complex exhibit an antibacterial activity towards all the tested Gram-positive and Gram-negative bacteria. By comparison with Gentamycin taken as the standard drug reference, the complex is found to show excellent activity against $B$. subtilis and $P$. vulgaris as proved by the inhibition zone (IZ) values in the range $25-26 \mathrm{~mm}$. The IZ values calculated for the ligands, tested in concentrations of $100 \mu \mathrm{g} / \mathrm{mL}$ against the same microorganisms, range between $15 \mathrm{~mm}$ and $21 \mathrm{~mm}$. Besides, the tests indicate that both the ligands and the complex show a moderate activity against $S$. aureus and E. coli.

The increased activity of metal complexes relative to their free organic ligands can be explained by the chelation theory [43]. Actually, chelation reduces the polarity of the central metal ion because its positive charges are partially shared with the donor $\mathrm{N}$-atoms of ligands and there can be a delocalization of the electrons over the whole chelate [44]. Such a vision 
leads to consider an increase in the lipophilic character of the metal promoting the efficiency of its permeation through the microorganism lipoid layer resulting in effective and total destruction. Other factors such as solubility, conductivity, toxicity and bond length may also play a role in the improvement of this activity [45-47].

\section{Conclusion}

We report here on a newly identified complex $\left\{\left[2 \mathrm{Ni}(\mathrm{L} 1)_{2} \cdot 2 \mathrm{Ni}(\mathrm{L} 1)(\mathrm{L} 2)\right] .2\left(\mathrm{NO}_{3}\right)_{4} \cdot 2 \mathrm{H}_{2} \mathrm{O}\right\}$ which includes four $\mathrm{Ni}(\mathrm{II})$ centers. It was prepared in very good yield using $\mathrm{N} 1-((3,5-$ dimethyl-1H-pyrazol-1-yl)methyl)propane-1,2-diamine and N2-((3,5-dimethyl-1H-pyrazol-1yl)methyl) propane-1,2-diamine units as $\mathrm{N}$-tridentate ligands. This complex was characterized by EDX, FT-IR, UV-Visible spectroscopies. The peculiarity of its triclinic structure, determined from single-crystal $\mathrm{X}$-ray diffraction, is that four molecules $\mathrm{C}_{18} \mathrm{H}_{36} \mathrm{~N}_{8} \mathrm{Ni}$ of the complex (two isomers) have co-crystallized with $\mathrm{H}_{2} \mathrm{O}$ and $\mathrm{NO}_{3}$ units. All the $\mathrm{Ni}(\mathrm{II})$ centers display nearly octahedral environments. The crystal lattice is highly stabilized by the numerous hydrogen bonds that occur in the crystal structure. The prepared complex shows good thermal stability, four steps of degradation to the final $\mathrm{NiO}$ product were recorded by TG/DTG thermal analysis. Both the (L1) and (L2) ligands and the Ni(II) complex show promising antibacterial activity against a panel of Gram-positive and Gram-negative bacteria.

\section{Acknowledgments}

Bilateral project (CNR Italie and CNRST Morocco) project 12/2020; UMP Oujda/ICNRC Bari (R.T. and A.M.)

\section{ORCID Identification}

Abderrahim Titi : https://orcid.org/0000-0003-3330-5276

Saud Almutairi: https://orcid.org/0000-0001-5352-2783

Rachid Touzani :http://orcid.org/0000-0001-7333-697X

Monique Tillard :https://orcid.org/0000-0002-0609-7224

Belkheir Hammouti : https://orcid.org/0000-0003-3673-7904 


\section{Reference}

[1] S. Kankala, K.R. Rama, C. Kesari, F. Björkling, S. Nerella, P. Gundepaka, H. Guguloth, N. Thota . Syn. Comm. 50 (2020) 2997.

[2] M. Shuchao, O. Ben, W. Linan, Y. Lei, Curr. Comp.-Aid. Dru. Desig 16 (2020)564.

[3] S.K. Arepalli, C. Lee, J.K. Jung, Y. Kim, K. Lee, H. Lee. Bio, Med. Chem. Lett. 29 (2019) 2604.

[4] J-Jian Ji, Z-Qiang Zhu, L-Jin Xiao, D. Guo, X. Zhu, J. Tang, J. Wu, Z-Bo Xie, Z.-Gao Le, Org. Chem. Front. 21 (2019) 3693.

[5] Z. Qin, Y. Xi, S. Zhang, G. Tu, A. Yan, J. Chem. Inform. Mode 59 (2019) 1988.

[6] P. Zhang, E. Song, M. Jiang, Y. Song, J. Radi. Biol. (2020) 1.

[7] D. Foster, V. Clinics, J. Smal. Anim. Prac. 50 (2020) 1215.

[8] A.C. Vieira, M.F. Silva, A. Ribeiro, J. Lima, J.S. Filho. Cardio-Oncology 6 (2020) 1.

[9] Christine Martinek Brent, Robert W. Shaffer, Evidence-Based Critical Care, Springer, Cham, 2017, p. 73.

[10] A. Burnett, L. Arthur, Trans. Amer. Clin. Climato. Assoc. 130 (2019) 51.

[11] Y. Kim, S. B.Austin, S.V. Subramanian, I. Kawachi, PLoS ONE 13 (2018) e0198841.

[12] R.C. Lucchetta, B.S. Riveros, R. Pontarolo, J. Basic. Appl. Pharmac. Sci. 39 (2018) 1.

[13] Y.L. Qiu, H.X. Zhong, T.T. Zhang, W.B. Xu, P.P. Su, X.F. Li, H.M. Zhang, ACS Appl. Mater. Interfaces. 10 (2018) 2480.

[14] N.S. Venkataramanan, G. Kuppuraj, S. Rajagopal, Coord. Chem. Rev. 249 (2005) 1249.

[15] A. Titi, I. Warad, S.M. Almutairi, M. Fettouhi, M. Messali, A. Aljuhani, R. Touzani, A. Zarrouk, Inorg. Chem. Comm. (2020) 108292.

[16] A. Titi, T. Shiga, H. Oshio, R. Touzani, B. Hammouti, M. Mouslim, I. Warad, J. Mol.Struc. 1199 (2020) 126995.

[17] A. Titi, H. Oshio, R. Touzani, M. Mouslim, A. Zarrouk, B. Hammouti, I. Warad, J. Clust. Sci. 12 (2020) 1.

[18] A. Titi, M. Messali, R. Touzani, M. Fettouhi, A. Zarrouk, N. Al-Zaqri, A. Alsalme, F.A. Alharthi, A. Alsyahi, I. Warad, Int. J. Mol. Sci. 22 (2020) 8787.

[19] A. Titi, M. Al-Noaimi, Y. Kaddouri, R. El Ati, E.B. Yousf, M. El Kodadi, R. Touzani, J. Mater. Today: Proc. 13 (2019) 1134.

[20] F.-.M. Wang, C.-.S. Lu, Y.-.Z. Li, Q.-.J. Meng, Acta Crystallogr. Sect. E E66 (2010) m594.

[21] X. Duan, J. Cai, J. Yu, C. Wu, Y. Cui, Y. Yang, G. Qian, Microporous Mesoporous Mater. 181 (2013) 99.

[22] X. Zhang, X.X. Wu, J.H. Guo, J.Z. Huo, B. Ding, J. Mol. Struct. 1127 (2017) 183-190.

[23] F. Wu, H. Tong, K. Wang, X. Zhang, J. Zhang, X. Zhu, W.K. Wong, J. Lumin. 177 (2016) 82.

[24] M.S. El-Gaby, M.M. Ghorab, Z.H. Ismail, S.M. AbdelGawad, H.M. Aly, Med. Chem. Res. 27 (2018) 72.

[25] A. Titi, M. Messali, R. Touzani, M. Fettouhi, A. Zarrouk, N. Al-Zaqri, A. Alsalme, F.A. Alharthi, A. Alsyahi, I. Warad, J. Mol. Liq. 315 (2020) 113778.

[26] F.J. Meng, T. Sun, W.Z. Dong, M.H. Li, Z.Z. Tuo, Arch. Pharm. 349 (2016) 168-174.

[27] A. El-Mekabaty, H.A. Etman, A. Mosbah, J. Heterocycl. Chem. 53 (2016) 894.

[28] F. Xue, J. Zhao, T.S.A. Hor, Dalton Trans. 42 (2013) 5150.

[29] M. Yang, W.J. Park, K.B. Yoon, J.H. Jeong, H. Lee, Inorg. Chem. Commun. 14 (2011) 189.

[30] A. Titi, M. Messali, B.A. Alqurashy, R. Touzani, T. Shiga, H. Oshio, M. Fettouhi, M. Rajabi, F.A. Almalki, T.B. Hadda, J. Mol. Struc. 1205 (2020) 127625. 
[31] A. Titi, I. Warad, M. Tillard, R. Touzani, M. Messali, M. El Kodadi, A. Zarrouk, J. Mol. Struc. 1217 (2020) 128422.

[32] A. Biswas, L.K. Das, M.G.B. Drew, C. Diaz, A. Ghosh, Inorg. Chem. 51 (2012) 1011110121.

[33] Bruker, APEX3. Version 2017.3-0, Bruker AXS, Inc., 2017.

[34] G.M. Sheldrick, Acta Crystallogr., Sect. A: Fundam. Crystallogr. 71 (2015) 3.

[35] G.M. Sheldrick, Acta Crystallogr., Sect. C: Cryst. Struct. Commun. (2015) 71.

[36] M. Zienkiewicz, A. Jabłonska-Wawrzycka, J. Szlachetko, Y. Kayser, K. Stadnicka, W. Sawka Dobrowolska, J. Jezierska, B. Barszcz, J. Sa', Dalton Trans. 43 (2014) 8599.

[37] L.J. Farrugia, ORTEP-3 for Windows, an update, J. Appl. Crystallogr. 45 (2012) 849.

[38] P.M. Takahashi, A.V.G. Netto, A.E. Mauro, R.C.G. Frem, J. Therm. Anal. Calo. 79 (2005) 335.

[39] M.H. Sadhu, A. Solanki, S.B. Kumar, Polyhedron 100 (2015) 206.

[40] A. Barakat, M. Al-Noaimi, M. Suleiman, A.S. Aldwayyan, B. Hammouti, T. Ben Hadda, S.F. Haddad, A. Boshaala, I. Warad, Int. J. Mol. Sci. 14 (2013) 23941.

[41] S. Odabasığlu, R. Kurtaran, A. Azizoglu, H. Karab, S. Öz, O. Atakol, Cent. Eur. J. Chem. 7 (2009) 402.

[42] A.M. El-Hendawy, A.M. Fayed, M.R. Mostafa, Transition Met. Chem. 36 (2011)351.

[43] M. Claudel, J.V. Schwarte, K.M. Fromm, Chemistry (Easton) 2 (2020) 849.

[44] E. Kremer, G. Facchin, E. Estévez, P. Alborés, J. Baran, J. Ellena, H. Torre, J. Inorg. Biochem. 100 (2006) 1167

[45] M. Pervaiz, A. Riaz, A. Munir, Z. Saeed, S. Hussain, A. Rashid, U. Younas, A. Adnan, J. Mol. Struct. 1202 (2020) 127284.

[46] S. Celen, E. Gungor, H. Kara, A.D. Azaz J. Coord. Chem. 66 (2013) 3170-3181.

[47] E. Gungor, S. Celen, D. Azaz, H. Kar Spectrochim. Acta Part A, 94 (2012) 216- 221 